\title{
A imigração brasileira na França: do tipo histórico às modalidades migratórias contemporâneas
}

\author{
Gisele Maria Ribeiro de Almeida* \\ Rosana Baeninger ${ }^{\star *}$
}

O cenário atual de intensa mobilidade do capital tem sido acompanhado por um crescente deslocamento internacional de população. As transformações sociais vivenciadas nas últimas décadas tornaram mais complexo o fenômeno da imigração e emigração internacionais, que se realizam sob “novas lógicas”, em especial devido à ampliação do mercado mundial e à dispersão da indústria e da produção de bens e serviços. É nesse contexto que o presente artigo reflete sobre a imigração brasileira na França após 1980, considerando as diferentes modalidades migratórias que compõem esse fluxo, as quais se redefinem na lógica da inserção do Brasil na rota das migrações internacionais. 0 caráter multifacetado da emigração de brasileiros e brasileiras para a França revela que, além dos históricos vínculos entre os países, as novas lógicas das migrações, no cenário geopolítico mundial do século XXI, anunciam a diversificação do fluxo de brasileiros e brasileiras em direção à França. A pesquisa de campo realizada na França, em 2012, com 82 imigrantes brasileiros evidenciou que há uma diversidade de perfis de migrantes e de modalidades migratórias. Essas modalidades foram engendradas a partir da leitura dos projetos migratórios e reconstruídas por meio do material obtido com as entrevistas semidirigidas realizadas com os imigrantes.

Palavras-chave: Migração internacional. Emigração-Brasil. Imigração-França. Determinantes da migração.

\footnotetext{
* Departamento de Ciências Sociais da Universidade Federal Fluminense, Campos dos Goytacazes-RJ, Brasil (gimralmeida@ gmail.com).

** Departamento de Demografia e Núcleo de Estudos de População, Universidade Estadual de Campinas (Unicamp), Campinas-SP, Brasil (baeninger@nepo.unicamp.br).
} 


\section{Introdução}

A presença de “novas lógicas migratórias” no século XXI (DUMONT, G., 2006) impacta os deslocamentos populacionais dentro e fora das fronteiras nacionais, com o surgimento de "novos migrantes" e de novas formas de instalação nas sociedades receptoras. Esses aspectos relacionam-se a uma diversidade de perfis de migrantes e de modalidades migratórias e, dado o caráter multifacetado do fenômeno, torna-se complexa a identificação do tipo migratório específico inerente à atual etapa econômica. No caso dos brasileiros e brasileiras na França, podem ser analisadas a pluralidade de fluxos e as diversas modalidades migratórias (WIHTOL DE WENDEN, 2001) que os compõem (ALMEIDA, 2013).

O texto apresenta, inicialmente, uma discussão em torno das modalidades migratórias (WIHTOL DE WENDEN, 2001) como recurso teórico-metodológico, considerando o entendimento das migrações diante das atuais exigências teóricas e conceituais engendradas pelas novas formas de mobilidade internacional do capital (SASSEN, 1988) e da população (LIVI BACCI, 2012). Nesse cenário, diferentes modalidades migratórias dividem o protagonismo na composição das migrações internacionais contemporâneas, em um contexto de mobilidade do capital e da força-de-trabalho crescentes.

0 artigo focaliza o tema da emigração brasileira, um fenômeno particularmente recente, identificado a partir dos anos 1980 . 0 contexto econômico do país naquele momento, associado às novas formas de reprodução global do capital (SALES, 1991), constitui o cenário no qual os emigrantes brasileiros começaram a buscar novos destinos, para além das fronteiras nacionais.

A França é um desses destinos. A imigração brasileira no país apresentou crescimento nos últimos anos, revelando processos sociais contemporâneos que constroem modalidades migratórias diversas, devido à diversidade de perfis de migrantes e dos constrangimentos e oportunidades que lhes são inerentes.

\section{A emigração brasileira e o destino "França"}

A crise econômica que assolou o Brasil na década de 1980 impactou o nível de emprego e as condições de vida da população, reverberando em fluxos inéditos de emigração no país (SALES, 1991). O fenômeno emigratório teve caráter inovador porque, historicamente, as migrações internacionais assumiram um sentido inverso no Brasil, servindo para a formação socioeconômica do país que ficou reconhecido por sua "vocação" de nação receptora (PATARRA; BAENINGER, 1995). No início, os países que mais receberam brasileiros foram, principalmente, Estados Unidos, Japão e Portugal; note-se, contudo, que já nos anos 1970 havia fluxo em direção ao Paraguai, particularmente ligado a uma dinâmica de fronteira (PALAU, 2001). Em período recente, os três primeiros países ainda absorvem mais da metade dos emigrantes brasileiros, segundo as estimativas do Ministério das Relações 
Exteriores do Brasil (MRE). ${ }^{1}$ Importante ressaltar que estes dados apresentam problemas na estimativa, principalmente devido à migração não documentada, que geralmente não é captada nas fontes de informações consulares. O MRE reconhece a dificuldade de mensurar essa população (com exceção para o caso japonês, pois se trata de uma emigração documentada) e explica que as estimativas consideram diversas fontes de dados secundárias:

[...] dados oficiais fornecidos por autoridades migratórias locais; censos oficiais; número de eleitores registrados na jurisdição; número de matriculados nos consulados; sondagens junto à comunidade; solicitações de passaportes e outros documentos por brasileiros; movimento geral da repartição e de consulados itinerantes; dados disponíveis sobre saída do país e retorno de brasileiros; percentuais de redução de remessas; publicações da Organização Internacional para as Migrações (OIM); estudos da OCDE; trabalhos acadêmicos e artigos na imprensa (BRASIL, 2012, p. 21).

Todavia, seja em função da intensificação do processo de mundialização, seja pela própria complexidade dos processos de mobilidade humana, assiste-se à configuração de “novas lógicas migratórias” (DUMONT, G., 2006), de “novas migrações” e de "novos migrantes" (WIHTOL DE WENDEN, 2001) no século XXI. É nesse novo contexto que também se manifesta a emigração de brasileiros, cuja presença tem crescido em países nos quais os elos que ligam origem e destino são menos evidentes, como é o caso da França e do próprio espaço de livre circulação europeu (ROSENFELD et al., 2009).

No século XIX e começo do XX, a presença de latino-americanos na França era restrita a fazendeiros ou cientistas que buscavam viver o glamour da belle époque e também mergulhar na vida cultural francesa (ROLLAND, 2008); viver na França, particularmente em Paris, fazia parte indispensável de um processo identitário, da vida social e cultural de determinados grupos sociais. A partir dos anos 1960, no âmbito da emergência de ditaduras no continente americano, um novo perfil de latino-americanos se fez presente na França, com o aparecimento de refugiados políticos. Nas últimas décadas, Rolland (2008) identifica uma terceira onda de migração oriunda da América Latina, que difere dos processos migratórios anteriores. Este panorama histórico do processo migratório de latino-americanos em seu conjunto, traçado pelo referido autor, também se mostra pertinente para o caso do fluxo Brasil-França. Pereira (2009) analisa o interesse das elites brasileiras do século XIX pela França, assim como a ditadura militar instituída em 1964 fez com que brasileiros e brasileiras buscassem refúgio naquele país (ROLLAND, 2008) e, mais recentemente, a emigração para a França representa também a busca de melhores oportunidades (BÓGUS, 1995; AMORIM, 2009; ALMEIDA, 2013).

\footnotetext{
$\overline{1}$ Estes dados são divulgados pela Subsecretaria-Geral das Comunidades Brasileiras no Exterior (SGEB) do Ministério das Relações Exteriores por meio de seu portal eletrônico (www.brasileirosnomundo.itamaraty.gov.br). De acordo com a SGEB, essas estimativas sobre o número de brasileiros residentes em países estrangeiros consideram informações contidas nos relatórios consulares (documentos que são enviados pelos Consulados e Embaixadas) e que abordam o volume de brasileiros residentes em suas respectivas jurisdições. Apesar dos limites de tais informações, sua potencialidade reside no fato de apontar as tendências recentes, em especial quanto ao destino, do fenômeno migratório internacional.
} 
De acordo com dados disponibilizados pelo MRE, havia 30 mil brasileiros vivendo na França em 2008, 60 mil em 2009, 80 mil em 2010, 44 mil em 2012 e 60 mil em 2013. Tais números indicam elevação na participação da França em relação ao destino do total de emigrantes brasileiros estimados pelo MRE: 1,0\% em 2007, 2,0\% em 2008, 2,6\% em 2010, $1,8 \%$ em 2012 e 2,1\% em 2013. O Censo Demográfico de 2010, do IBGE, indicou que, dos 491.645 emigrantes brasileiros no exterior, 17.743 estavam residindo na França, o que corresponde a 3,6\% do total de emigrantes brasileiros, segundo esta fonte de informação. ${ }^{2}$

Chama atenção a diferença no resultado do Censo Demográfico de 2010 quanto ao volume de brasileiros e brasileiras que residiam na França no momento censitário, o qual se apresenta muitas vezes menor do que a estimativa do MRE. Este fato se dá em função de serem oriundos de metodologias bastante distintas e que estão sujeitas a diferentes erros.

Do ponto de vista da sociedade de acolhimento, a participação dos brasileiros no total da população que não nasceu na França é pequena, menos de $1 \%$ de acordo com os dados do Institut National de la Statistique et des Études Économiques (Insee). Porém, considerando o contingente de latino-americanos residente naquele país, os brasileiros correspondem à segunda nacionalidade em todos os anos com informações divulgadas pelo Insee (1982, 1990, 1999 e 2008). Em 2008, os brasileiros representavam um quinto da população latino-americana na condição de estrangeiros e imigrantes na França.

Torna-se importante ressaltar que o Insee divide suas informações de acordo com a definição de imigrantes e de estrangeiros. Imigrantes são pessoas que não nasceram na França, vivem lá e que obtiveram a cidadania francesa. Já os estrangeiros são pessoas que não nasceram na França, moram no país e não possuem a cidadania francesa. De acordo com essa definição, os imigrantes brasileiros/brasileiras naturalizados franceses passaram de 5.300 em 1982 para 25.000 em 2008 e o contingente na definição de estrangeiros aumentou de 3.800 para 14.000 , nesse mesmo período. Observa-se, portanto, o incremento de imigrantes e estrangeiros brasileiros/brasileiras, segundo os dados oficiais franceses. No entanto, tais números diferenciam da estimativa do MRE do Brasil (30 mil brasileiros/ brasileiras na França em 2008), especialmente pelo fato de o Insee tratar de categorias jurídicas francesas, pressupondo a imigração documentada.

Ainda que o volume de emigrantes brasileiros e brasileiras estimado pelo MRE para 2013 na França seja menor (60 mil pessoas) quando comparado aos contingentes residentes nos Estados Unidos (1.006.842 pessoas), no Paraguai (459.760) e no Japão (186.051), este fluxo compõe o cenário das migrações internacionais na sociedade contemporânea. De fato, as considerações de Laurens (1992) levam a investir nos ganhos teóricos que uma pesquisa sobre um fenômeno relativamente marginal pode trazer ao conhecimento

\footnotetext{
${ }^{2}$ No caso do Censo Demográfico de 2010, houve uma pergunta no questionário do universo, para que o respondente indicasse se havia pessoa daquele domicílio residindo no exterior; as discussões acerca dos resultados censitários para este quesito apontam para uma subenumeração no volume de emigrantes brasileiros no exterior. De um lado, se a família inteira emigrou, ela não respondeu ao censo e, portanto, os emigrantes não foram contabilizados e, de outro, caso a pessoa do domicílio se encontre em uma situação indocumentada no país de destino, pode ocorrer uma omissão desta informação por parte do respondente.
} 
científico. A pequena expressividade numérica do fluxo o colocou como um problema de pesquisa particular, reforçando nosso interesse pela seletividade dessa migração e pelos processos sociais que vinculam de forma particular origem e destino migratório, em conformidade com o "perfil de migrante" e com sua inserção na sociedade francesa. Nessa concepção, as modalidades migratórias (WIHTOL DE WENDEN, 2001; BAENINGER, 2012) indicaram distintos processos relacionados à migração, refletindo uma diferenciação entre tais imigrantes brasileiros/brasileiras e as posições ocupadas por eles/elas no espaço social (BOURDIEU, 1989, 2004, 2011).

\section{0 tipo migratório histórico do fluxo Brasil-França}

A história das relações franco-brasileiras começa ainda no século XVI, com o projeto de se criar a chamada "França Antártica”, uma colônia francesa no Brasil que na época era domínio da Coroa Portuguesa (TAVARES, 1979). 0 empreendimento alcançou importantes êxitos iniciais, logrou a construção de um forte, conseguiu o apoio dos Tupinambás, mas o projeto foi completamente derrotado pelos portugueses em 1565, ainda que o evento tenha servido para aumentar o interesse da França pelo Brasil (TAVARES, 1979).

De acordo com Carelli (1994), os relatos sobre o território "selvagem" brasileiro tiveram também grande repercussão na configuração do imaginário francês sobre "paraísos lendários”, principalmente devido às narrativas que chegavam à França a partir da experiência dos aventureiros e pensadores que exploravam o "Novo Mundo". No século XIX, esse interesse foi reorientado e a independência do Brasil em 1822 teve papel fundamental nesta mudança. Isso porque, até então, eram os franceses que vinham ao Brasil, sendo que, após esse período, foram os brasileiros que seguiram para a França, para estudar em suas universidades, com um movimento de estudantes bolsistas financiados pelo governo brasileiro (TAVARES, 1979).

Carelli (1994) destaca que, paralelamente a isso, as ideias francesas continuaram se infiltrando em instituições e influenciando intelectuais brasileiros, como mostra a relevância que o positivismo, baseado no pensamento de Augusto Comte, teve para a instauração da República no país. Durante o século XX, os laços entre Brasil e França foram reforçados, sendo notáveis a fascinação e a admiração que a França exerceu sobre diversos e importantes estratos brasileiros, especialmente em certos meios intelectuais e artísticos (CARELLI, 1994). No âmbito acadêmico, projetos de parceria científica foram essenciais na formação e estruturação de importantes institutos e universidades no Brasil, como é o caso da Universidade de São Paulo (TAVARES, 1979). Todo esse histórico resultou em uma expressiva herança cultural francesa no Brasil, consolidada em instituições e grupos sociais, de forma que houve, e ainda há, um fluxo de estudantes brasileiros na França, em grande medida, relacionado à francofilia que emergiu e se consolidou a partir dessas ligações históricas. Assim, dessas relações entre a França e o Brasil, nasce um suposto estereótipo de "elite", associado à presença, na França, de latino-americanos em geral e de brasileiros em particular (ROLLAND, 2008). 
Se a historicidade das relações entre o Brasil e a França, particularmente no âmbito das relações culturais, evidencia um protagonismo de ideias francesas em algumas instituições brasileiras, em especial de cunho acadêmico, tais “cruzamentos culturais” (CARELLI, 1994) ficaram impregnados em certos espaços, promovendo e estimulando um forte intercâmbio no âmbito acadêmico e intelectual (XAVIER DE BRITO, 1991, 2009; MAZZA, 2009; ALMEIDA, 2012). Essa dimensão histórica ilumina a compreensão de um fluxo duradouro e contínuo de estudantes brasileiros interessados nas universidades francesas.

A reconstrução analítica do histórico do fluxo estudantil de brasileiros para a França e a atual expressividade desse tipo de mobilidade (ALMEIDA, 2013) permitem a consideração de que a migração estudantil pode ser identificada como o tipo migratório histórico do fluxo Brasil-França. Porém, a hegemonia desse perfil de migrantes mostra-se questionável atualmente, com o surgimento dos "novos" emigrantes brasileiros/brasileiras e das atuais formas de mobilidade inauguradas nas últimas décadas. Além da mobilidade estudantil, a imigração brasileira na França - particularmente após 1990 - é feita também por pessoas que se deslocam por diferentes motivos e contextos.

\section{A pesquisa de campo sobre a imigração brasileira na França}

Os estudantes brasileiros e brasileiras constituem um importante contingente de imigrantes na França; de um lado, expressam a relevância da historicidade e da atualidade do fluxo migratório e, de outro, se diversificam, distanciando-se dos condicionantes presentes nos fluxos migratórios iniciais de uma elite intelectual brasileira. Além dessa diversidade na emigração brasileira de estudantes para a França, há uma ampliação de perfis migratórios que também permitem compor a construção de diferentes modalidades de migrações no fluxo Brasil-França.

A partir da pesquisa de campo realizada na França, entre maio e outubro de 2012, foram feitas 82 entrevistas semiestruturadas com imigrantes brasileiros e brasileiras residentes em diferentes cidades francesas (ALMEIDA, 2013). Em relação à constituição do corpus da pesquisa, o recorte cronológico focalizou a imigração brasileira na França após 1980, devido ao nosso interesse em estudar as migrações internacionais atuais, mesmo sabendo da importância dos fluxos anteriores em diferentes momentos da história brasileira (TAVARES, 1979).

Os sujeitos migrantes foram definidos a partir de alguns critérios. Excluíram-se os turistas (mesmo quando estabelecem residência temporária), os estudantes de idioma francês de curta duração e também os chamados estudantes "bolsistas-sanduíche”. Estes últimos, apesar de poderem permanecer até um ano na França, devem retornar ao Brasil em função do compromisso com a bolsa de estudos, sendo que a expectativa temporal do deslocamento (ROBERTS, 1995) tende a se manter inalterada.

Mas outras situações de estudantes foram incluídas na pesquisa de campo e nas entrevistas. É o caso de alunos/alunas de mestrado ou doutorado pleno, ou aquele estudante 
que foi ou está na França para fazer uma formação integral, ${ }^{3}$ estabelecendo uma estada mais duradoura e vivenciando uma realidade mais próxima da condição de "estrangeiro" (SCHUTZ, 1944).

É importante destacar que a definição do imigrante brasileiro/brasileira adotada pela pesquisa é diferente daquela do Insee, que diferencia os imigrantes e os estrangeiros em função da aquisição da nacionalidade francesa. Nesta pesquisa, todos os brasileiros e brasileiras que viviam ou viveram na França por mais de um ano (exceto bolsistas "sanduíche" e estudantes com outras bolsas de agências brasileiras que implicam vínculos e compromisso de retorno ao Brasil) foram considerados imigrantes, independentemente de terem sido naturalizados ou não.

Como se trata de uma população pequena e dispersa, os entrevistados foram identificados e localizados pelo método da "bola de neve" (WEISS, 1994; MAY, 2004; PIRES, 2010), usado nas Ciências Sociais para indicar a seleção de amostragem de forma não probabilística, no qual alguém indica uma ou mais pessoas, que, por sua vez, podem sugerir outros nomes. De acordo com May (2004), essa técnica é recomendada e utilizada em pesquisas cuja população-alvo está oculta e/ou dispersa, permitindo que o pesquisador se aproxime de situações sociais específicas. Nesses casos, é mais fácil que informantes privilegiados e/ou pessoas da própria população conheçam outros membros e os indiquem do que o próprio investigador conseguir identificá-los. A mesma técnica foi usada por Sales (1999) em seu estudo sobre imigração brasileira em Boston. Margolis (1994) também explicitou a opção por essa técnica, que cria uma rede de informantes, para sua pesquisa realizada sobre os imigrantes brasileiros em Nova Iorque.

As entrevistas foram realizadas em Aix-en-Provence, Lille, Lyon, Marselha, Montpellier, Paris, Rennes, Estrasburgo, Nice, Toulon e outras pequenas cidades próximas a elas. 0 procedimento utilizado foi o estabelecimento do contato (correio eletrônico ou telefone) com explicitação do pedido de colaboração, seguido pelo agendamento do encontro. A hora e o local de realização da entrevista ficaram sempre a critério do entrevistado, bem como a opção de registro da entrevista, se seria por meio de gravação ou por anotações. Todos os entrevistados foram informados sobre a pesquisa em curso e sabiam que seus depoimentos seriam utilizados em estudo, sendo ressaltado o compromisso de que suas identidades seriam preservadas. Por isso, quando há referência aos entrevistados e às entrevistadas, estes aparecem identificados por nomes fictícios.

A pesquisa de campo mostrou, por observação direta e informação, que há algumas periferias da região parisiense que concentram brasileiros e brasileiras, mas, de forma geral, esses imigrantes na França não são facilmente localizados. Nesse sentido, a inserção em redes de brasileiros e brasileiras e os efeitos da "bola da neve" foram essenciais para a pesquisa. Como era do nosso interesse a busca de uma diversidade de perfis de migrantes e de modalidades migratórias, mais do que intensificar os contatos em um mesmo grupo,

\footnotetext{
${ }^{3}$ Destaca-se, no entanto, que não foram considerados imigrantes os estudantes com bolsas de agências de fomento brasileiras e/ou com outros vínculos institucionais no Brasil que pudessem implicar uma exigência de retorno.
} 
buscou-se obter o maior número possível de pontos de partida e, para isso, os informantes privilegiados foram fundamentais.

A estratégia utilizada para localização e realização das entrevistas viabilizou reunir perfis imigratórios diferenciados a partir de contatos desde o Brasil: foram realizadas entrevistas em Paris e sua região e nas regiões leste, oeste, sudeste e sul da França. Algumas cidades são muito pequenas e, para preservar a identidade dos entrevistados, foi indicada a cidade vizinha de referência ou ainda a região da França na qual se situa a cidade. A dispersão geográfica dos entrevistados também reflete o esforço de se ampliar a diversidade de situações migratórias e de suas distintas modalidades. Tratou-se de uma seleção não probabilística de brasileiros e brasileiras imigrantes na França, a partir dos quais se pode aplicar a técnica da bola de neve. Houve entrevistados diretamente ligados à pesquisadora que foram contatados de diversas formas, particularmente por meio de grupos formados no Facebook, de lista eletrônica de troca de mensagens da Associação dos Pesquisadores e Estudantes Brasileiros na França (Apeb-FR), indicações dos informantes privilegiados, redes pessoais da pesquisadora e contatos estabelecidos oportunamente em eventos que reuniram brasileiros na França.

\section{Modalidades migratórias atuais e novos fluxos de imigrantes entre Brasil-França}

A pesquisa de campo realizada evidenciou que há uma diversidade de perfis de migrantes e de modalidades migratórias. Essas modalidades migratórias foram engendradas a partir da leitura dos projetos migratórios (MA MUNG, 2009) e reconstruídas por meio do material obtido com as entrevistas semidirigidas conduzidas junto aos imigrantes (ALMEIDA, 2013).

As modalidades migratórias foram construídas priorizando as motivações que estão na raiz dos projetos migratórios e não, por exemplo, a condição jurídica do imigrante na sociedade de destino. Isso porque considerou-se que a situação legal do migrante e da migração é, muitas vezes, resultado de sua trajetória, e não expõe, em muitos casos, os contornos de processos sociais particulares que explicariam essas migrações. 0 agrupamento de brasileiros e brasileiras que obtiveram a cidadania francesa, por exemplo, esconde uma diversidade muito grande de perfis e de modalidades migratórias. Por isso, eles foram classificados tendo em vista as motivações iniciais relacionadas ao projeto migratório e ao tipo de visto que esse imigrante tinha antes mesmo de se beneficiar de condições jurídicas mais estáveis.

Considerando as migrações internacionais contemporâneas como migrações transnacionais (GUARNIZO, 2003), a diversidade de situações que delas advém é conceitualizada aqui como modalidades migratórias (WIHTOL DE WENDEN, 2001), as quais são inerentes às novas lógicas migratórias na contemporaneidade (DUMONT, G., 2006). Assim, a partir de tais perspectivas teóricas e das respectivas evidências empíricas da pesquisa qualitativa junto aos imigrantes brasileiros na França, foi possível identificar as seguintes 
modalidades migratórias: profissionais altamente qualificados; estudantes; laboral; afetiva; e "cosmopolita".

Em algumas destas modalidades, seus desdobramentos e ramificações mostraram-se importantes para encontrarmos dimensões explicativas sobre elas. Além disso, tais modalidades podem se entrecruzar e se sobrepor e, desse modo, buscamos eleger em cada grupo de entrevistado as especificidades mais relevantes diante da heterogeneidade de perfis migratórios. Por exemplo, as migrações de profissionais qualificados abarcam tanto os quadros de gerência de organizações privadas multinacionais, que reverberam na mobilidade de executivos, quanto a mobilidade de cientistas e pesquisadores. Na imigração de estudantes, identificamos diversas formas de conceber e realizar seus projetos migratórios, ${ }^{4}$ indicando que as motivações iniciais atreladas ao estudo - em um primeiro momento - se convertem em uma migração de trabalho ou de formação de família na França, com casamentos e nascimentos de filhos; ou seja, há uma atualização constante dos projetos migratórios que repercutem, inclusive, em mecanismos de permanência e sedentarização (BOULY DE LESDAIN, 1999).

Dessa forma, no que tange às modalidades construídas e considerando as 82 entrevistas, seis entrevistados foram identificados na modalidade migratória de profissionais altamente qualificados, 19 compuseram a modalidade migratória estudantil, 22 casos evidenciaram aspectos associados à modalidade migratória laboral, 28 entrevistados/ entrevistadas foram incluídos na modalidade migratória afetiva e sete foram integrados na modalidade migratória cosmopolita. 0 Quadro 1, no Anexo, apresenta de forma resumida algumas características dos/as entrevistados/as.

Além da classificação dos entrevistados, as modalidades migratórias foram também pensadas analiticamente, isto é, procurou-se identificar os processos sociais que engendraram essas formas de mobilidades. Por exemplo, a mobilidade internacional de executivos inseridos em corporações privadas transnacionais não pode ser desassociada das transformações advindas com a globalização e suas implicações para os processos produtivos e para as formas de gestão organizacional que se configuram nesse contexto (CASTELLS, 1999). É nesse sentido que a investigação sobre o fluxo Brasil-França, aqui analisado a partir das modalidades migratórias, buscou conciliar os interesses e estratégias dos imigrantes, com as coações e as possibilidades que esses agentes experimentam dados os seus respectivos posicionamentos no espaço social (BOURDIEU, 2004, 2011).

Considerando a modalidade migratória de profissionais altamente qualificados, nota-se que, enquanto as fronteiras nacionais estão cada vez mais fechadas para os trabalhadores, diversos países “disputam” profissionais qualificados por meio de políticas migratórias seletivas baseadas em critérios de capital humano (DUMONT, J., 2006). A França é um dos países que adotam essas políticas seletivas, tendo como objetivo atrair profissionais

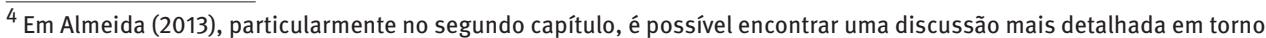
da ideia de projeto migratório e de como autores franceses têm contribuído para o refinamento e aprofundamento do uso heurístico dessa ideia em estudos migratórios (MA MUNG, 2009; BOULY DE LESDAIN, 1999; BOYER, 2005).
} 
qualificados, particularmente para sanar as carências do mercado de trabalho (WAGNER, 1998). Na pesquisa realizada, foram identificados dois perfis de trabalhadores migrantes qualificados: executivos e cientistas. Os executivos experimentam a chamada "migração de carreira” (TILLY, 1986), situação em que os indivíduos (e suas famílias) migram pelas oportunidades profissionais que surgem nas organizações nas quais eles já trabalhavam antes. Normalmente, a possibilidade de ir para outro país está ligada à inserção desses profissionais executivos em filiais de empresas multinacionais instaladas no país. Entre as entrevistas realizadas na França, houve apenas um caso de uma mulher como profissional executiva e que ocupava um cargo de direção no âmbito administrativo. Além dela, foram entrevistados dois homens, ambos engenheiros elétricos, que ocupavam cargos gerenciais ligados à produção.

No caso da mobilidade de cientistas, não se verifica a existência de um protagonismo das organizações, tal como se manifesta na mobilidade de trabalhadores qualificados vinculados às empresas multinacionais. Os cientistas parecem estar mais sujeitos aos deslocamentos em função de parcerias institucionais, da oferta de financiamento e de melhores condições de trabalho e de recursos para a pesquisa (VIDEIRA, 2013). Essas motivações apareceram enquadradas nessa categoria de mobilidade. São duas mulheres (uma socióloga e uma física) e um homem (físico). Todos entraram na França com visto de longa permanência, categoria "científico"; um deles já havia obtido o título de residente, por meio de um contrato de trabalho por tempo indeterminado, manifestando, inclusive, na entrevista, seu interesse em uma situação de instalação "definitiva” ou de um "fluxo voluntário de caráter irreversível” (DOMENACH; PICOUET, 1990).

No caso das motivações relacionadas ao trabalho, visando melhorar o padrão de vida ou conseguir "juntar dinheiro", os imigrantes foram agregados na modalidade migratória laboral. A situação da economia brasileira na primeira década do século XXI melhorou expressivamente em relação aos anos 1980, quando se iniciou o processo emigratório. No entanto, isso não significou o fim da emigração de brasileiros para a França, pois o que se verifica no âmbito das migrações internacionais contemporâneas é uma combinação de "novos" e "velhos" fatores na promoção dos fluxos, um contexto no qual os fatores laborais e econômicos se conjugam a critérios de outra natureza no processo decisório que culmina na migração. ${ }^{5}$ Uma evidência disso é que, dos 22 brasileiros que foram classificados na modalidade migratória laboral, sete chegaram à França com uma experiência anterior de migração internacional. Houve casos de que a ida para a França foi pensada exatamente

\footnotetext{
${ }^{5}$ Apesar de não estar incluída na lista de entrevistados por estar na França há menos de um ano quando concedeu a entrevista (em Paris, no dia 17/08/2012), o caso do projeto migratório de Catarina é elucidativo quanto a esse ponto. Ela deixou o Brasil aos 25 anos com o marido e um filho, em fevereiro de 2012. 0 casal vendeu a casa que possuía na periferia de Curitiba e foi para a França, onde vivia o tio do marido. Ela disse que seu intuito era "ter mais experiência, aprender um idioma", mas pelos motivos alegados por ela, para justificar a migração, isso também queria dizer "ganhar dinheiro". 0 caso de Catarina é um exemplo de como os fatores de atração e expulsão são limitados mesmo para se entender a migração laboral, pois ela saiu do Brasil em um contexto no qual o mercado de trabalho brasileiro estava muito mais favorável do que na França, que em 2012 sofria os efeitos da crise econômica europeia, sendo inclusive uma fase marcada pelo retorno de brasileiros (FERNANDES; NUNAN; CARVALHO, 2011) e pela imigração de profissionais e trabalhadores europeus (ALCARAZ, 2012).
} 
por se desconsiderar a possibilidade de retornar ou de permanecer no Brasil, após uma experiência prévia de emigração internacional, como são os casos de dois entrevistados que foram para a França “fugindo" da crise econômica na Espanha, onde viviam anteriormente; outros dois brasileiros haviam reemigrado do Brasil após terem vivido na Inglaterra e de terem sido repatriados ao Brasil porque estavam em condição indocumentada.

Os imigrantes entrevistados, incluídos na modalidade laboral, eram, em sua maioria, homens que trabalhavam em serviços ligados à reforma de residências e prédios, atividades associadas ao setor da construção civil. Há fortes indícios de que a entrada dos brasileiros nesse segmento do mercado de trabalho na França tenha sido facilitada pela forte presença portuguesa na atividade. Existe uma antiga e volumosa migração portuguesa para a França, e os trabalhadores portugueses estariam até os dias de hoje "super-representados" quanto à inserção ocupacional nesse ramo da atividade em relação aos franceses e a outros grupos estrangeiros (CORDEIRO, 1999). De fato, a recente imigração brasileira na França beneficia-se da presença de imigrantes portugueses e de seus descendentes, particularmente vinculados a esse ramo de atividade. Isso porque a barreira linguística para trabalhadores brasileiros manuais na França tende a desaparecer ou ser minimizada quando se trata dessas atividades ligadas aos portugueses; nesse contexto, os brasileiros conseguem arrumar trabalho mesmo quando não falam o francês.

Em relação às mulheres, seguindo os passos dos homens que trabalham com portugueses na construção civil, as brasileiras tendem a exercer algumas atividades peculiares aos grupos imigrantes e em segmentos que também concentram portuguesas, como serviços de limpeza, que podem ser a realização de faxinas em residências ou limpeza de escritórios comerciais, além do serviço de zeladoria, em francês denominado "concierge" ou "gardienne d'immeuble", que também foi uma ocupação anteriormente designada às imigrantes portuguesas na França.

Apesar de haver essa sintonia em relação à presença de imigrantes portuguesas nesse ramo de serviços, a inserção ocupacional das brasileiras nas atividades de cuidado na França remete a um cenário mais amplo, e o significado desta prevalência laboral está intimamente relacionado ao funcionamento da economia global e ao crescimento das atividades ligadas ao cuidado (MOROKVASIC, 2010; ZELIZER, 2008).

Outro segmento laboral que agrega uma parcela expressiva de brasileiros e brasileiras que vivem na França refere-se ao universo artístico, que é bastante receptivo em comparação com as possibilidades de inserção laboral que os artistas encontram no Brasil (REIS, 2012). Foi entrevistada quase uma dezena de imigrantes que trabalhavam ou trabalharam na França como artistas, envolvendo atividade de dança, canto, música, ensino de capoeira, etc. Também se verificou um fluxo antigo, e que se mantém ainda hoje, de transexuais que trabalham no mercado de sexo (VALE, 2009).

O contexto contemporâneo da era da mobilidade (CASTLES; MILLER, 2004; URRY, 2000) amplia os espaços da migração e os espaços de pertencimento mesmo para sedentários, em função das novas tecnologias de informação e comunicação e de suas ferramentas, 
que permitem as pessoas moverem-se virtualmente e estabelecerem novas formas de presença, consolidando espaços transnacionais (GLICK-SHILLER, 2007). Nesse novo cenário, as migrações motivadas pela afetividade ganham destaque. Isso pode ocorrer no âmbito dos deslocamentos familiares, nos quais os cônjuges migram para preservar a unificação familiar, ou ainda com as mudanças motivadas "por amor”, casos em que a migração é resultado de uma relação amorosa estabelecida com um parceiro estrangeiro. Entre os entrevistados foram identificados 28 casos em que o motivo para a emigração teve caráter familiar ou matrimonial. Entre estas migrações de caráter afetivo, há apenas dois casos nos quais a migração foi para preservar ou garantir a união familiar com um cônjuge brasileiro (duas mulheres). Nas demais ocorrências (26), a emigração no Brasil e a imigração na França foi motivada pelo casamento, pois o deslocamento efetuado foi viabilizado devido à formação familiar com um cônjuge estrangeiro.

Entre os casos de casamentos mistos, sete situações foram de brasileiros e brasileiras que conheceram seus cônjuges franceses na França: seis mulheres estavam na França trabalhando, estudando ou em viagens de lazer, e um homem estava a passeio.

Entre os casos de relacionamentos iniciados fora da França, há 14 ocorrências nas quais o/a cônjuge brasileiro/a conheceu o/a cônjuge estrangeiro/a no Brasil e cinco casos em que o casal se formou em outro país (Inglaterra, Austrália, Suiça, Irlanda e Guiana Francesa).

Foram considerados na modalidade migratória "cosmopolita" aqueles deslocamentos motivados, em grande medida, por uma predisposição do agente em "acolher a migração" (MA MUNG, 2009); indivíduos que mostraram interesse em conhecer outras culturas ou em viajar. São agentes cujas disposições conformam um "gosto" pela mobilidade, viabilizando inclusive que essa disposição seja expressão de seus "estilos de vida" (BOURDIEU, 1989).

Ainda que se reconheça que alguns migrantes que foram "enquadrados" na modalidade migratória "laboral” ou "afetiva” podem ter a mesma disposição para "ser móvel”, a diferença manifesta-se devido ao peso relativo dos constrangimentos estruturais. Estes "migrantes cosmopolitas" tiveram poucos obstáculos, ou quase nenhum, para realizar seus projetos migratórios. Isso se explica pela posse de capital econômico ou cultural em quantidade ou de forma privilegiada, ou ainda por terem acesso às facilidades jurídicas garantidas pela cidadania europeia, obtida por origem familiar.

Entre as modalidades migratórias contemporâneas no fluxo Brasil-França identificadas pela pesquisa, aquela referente à mobilidade estudantil parece ser a mais complexa: de um lado, por trazer as ressignificações de suas raízes históricas imperiais e as novas lógicas no mundo globalizado e, de outro, por atestar uma condição jurídica de imigrante documentado na França. Assim, na modalidade migratória estudantil, é preciso ressaltar que o fato de estar em uma mesma condição documentada (visto de estudante) não indica 
o mesmo processo migratório e nem a homogeneidade dos grupos sociais envolvidos nesta categoria de visto.

No que se refere aos estudantes (com mais de um ano de residência na França e com a intenção de formação integral financiada por bolsas internacionais ou recursos próprios), os motivos para a ida à França foram bastante diversificados. Encontramos, entre os entrevistados, distintos condicionantes e/ou motivações relacionados aos projetos migratórios desses/dessas imigrantes: obtenção de uma bolsa de estudos de agências internacionais; contato institucional prévio; interesse particular em uma formação na França; incentivo de amigos ou parentes que iam para a França ou que lá estavam; desejo de sair do Brasil e/ou estudar fora, com aspectos a favor da França, e até mesmo em função de aspectos afetivos e pessoais.

Esse leque de motivos que compõem distintos projetos migratórios de brasileiros e brasileiras estudantes na França sugere que a modalidade migratória estudantil é constituída por estudantes que encontraram na França as oportunidades de lá permanecerem com bolsas de estudos ou ainda com recursos próprios. Tais motivos são construídos socialmente pela política de acolhimento de estudantes estrangeiros da França, ou ainda pelo menor custo, quando comparado ao de outros países, como os Estados Unidos ou a Inglaterra; as taxas que vigoram nestes países, conforme foi revelado por alguns entrevistados, foram decisivas para fomentar a ida para a França, que se colocou como a opção de mais baixo custo.

Entre os motivos para os estudantes escolherem a França, alguns declararam o interesse em estudar fora do país como parte do crescimento de experiências internacionais no processo de formação pessoal, escolarização e profissionalização; é nesse sentido que Mazza (2009) aponta que a difusão mais recente do acesso ao ensino superior no Brasil engendrou a adoção de novas "estratégias" de distinção, entre elas a de estudar no exterior. Nesses casos, por exemplo, a escolha da França foi justificada por um interesse específico pelo idioma ou pelo pensamento francês, demonstrando uma estratégia pessoal distintiva num mercado simbólico que valoriza o cosmopolitismo. Tais estudantes, portanto, têm seus projetos migratórios muito mais inseridos na modalidade migratória cosmopolita do que na própria modalidade migratória estudantil.

A condição de estudante foi também utilizada como estratégia para viabilizar a entrada e permanência documentada na França. Assim, mesmo na condição de estudante pudemos identificar mudanças na expectativa temporal (ROBERTS, 1995) de imigrantes brasileiros e brasileiras, com o alongamento do tempo de permanência na França, mesmo após o término dos estudos, quer seja por relações afetivas, quer seja pelas vantagens de se morar e trabalhar na França. Assim, para os estudantes que apostam no projeto emigratório, a instalação definitiva na França é resultado de esforços e estratégias empreendidos pelo "estudante" para se tornar um “imigrante". 


\section{Considerações finais}

Os caminhos que levam brasileiros a migrar para a França não são os mesmos para diferentes perfis de migrantes. Profissionais qualificados, trabalhadores manuais, estudantes, migrantes "por amor" e "cosmopolitas" deixaram o Brasil e imigraram na França em função de interesses e estratégias diversas que guardam intrínsecas relações com processos sociais que viabilizaram, suportaram e direcionaram esses deslocamentos. Essas análises fundamentadas na pesquisa de campo sobre a imigração brasileira na França evidenciam não apenas o caráter multifacetado do recente fluxo Brasil-França, mas também dos processos sociais que podem explicar essas migrações.

As modalidades migratórias (WIHTOL DE WENDEN, 2001) foram construídas a partir da pesquisa de campo, tomando como base os projetos e os processos migratórios identificados empiricamente. A escolha dos projetos dos agentes que migram como base de uma tipologia foi uma opção metodológica pensada especificamente para fazer face ao impasse analítico que enxerga a migração como resultado de condicionantes macroestruturais; um cenário no qual o migrante tem pouca ou nenhuma capacidade de agência, ou ainda que entende a migração como resultado da decisão individual, explicitando o papel da agência do migrante diante dos constrangimentos dados pela realidade social.

Contribuir para a discussão que tem combatido essa polaridade de análise tornou-se um objetivo importante para a pesquisa. Nesse sentido, o presente estudo procurou contemplar essas novas abordagens de análise, partindo da consideração de que as formas, como as coações e os níveis de liberdade, que se manifestam na experiência dos migrantes são específicas em função de suas respectivas posições sociais. Em outras palavras, as motivações para migrar - como reflexos dos interesses e estratégias (BOURDIEU, 2004, 2011) - foram tomadas como referências para o delineamento das modalidades migratórias. Cabe destacar que, como ocorre em toda construção tipológica, tal segmentação delimitou fronteiras que não existem nos processos sociais empíricos. Isto é, a busca de melhores condições de vida e de trabalho associada com frequência à modalidade migratória laboral também pode ser uma motivação importante de emigrantes brasileiros que foram "identificados" como sendo casos de modalidade migratória afetiva. A dimensão "cosmopolita" também pode se mesclar às motivações dos profissionais qualificados e da mobilidade estudantil, apenas para citar alguns exemplos.

É importante reconhecer que as modalidades migratórias identificadas foram "reconstruídas" em função de processos sociais e migratórios específicos e que estão relacionados aos resultados obtidos com a pesquisa de campo realizada. Isto é, essas modalidades foram formalizadas a partir do corpus da pesquisa, expressando, dessa forma, a dimensão "seletiva" da própria metodologia: diferentes entrevistados nos levariam, muito provavelmente, a uma configuração distinta de modalidades migratórias.

No entanto, tais modalidades, que foram construídas e reconstruídas pela identificação de processos sociais e migratórios e pelas motivações de brasileiros e brasileiras 
para migrar para a França, apontam a necessidade de aprofundarmos estudos e análises específicos sobre os fluxos migratórios, suas causas, motivações, direções e sentidos em meio à nova lógica das migrações transnacionais no século XXI.

\section{Referências}

AMORIM, M. A. Para além de partidas e de chegadas: migração e imaginário entre o Brasil e a França, na contemporaneidade. Belo Horizonte: FAFICH/UFMG, 2009.

ALCARAZ, R. C. Rutas y dinámicas migratorias entre los países de América Latina y el Caribe (ALC), y entre ALC y la Unión Europea. Bruselas: Organización Internacional para las Migraciones (OIM), 2012. Disponível em: 〈publications.iom.int〉. Acesso em: 25 jul. 2013.

ALMEIDA, G. M. R. De estudante à migrante: percursos e percalços de brasileiros na França. In: PADILLA, B. et al. (Dir.). Novas e velhas configurações da imigração brasileira na Europa. Lisboa: ISCTE, 2012. p. 69-83.

. Au revoir, Brésil: um estudo sobre a imigração brasileira na França após 1980. Campinas: IFCH/Unicamp, 2013.

BAENINGER, R. Fases e faces da migração em São Paulo. Campinas: Nepo/Unicamp, 2012.

BÓGUS, L. M. Migrantes brasileiros na Europa Ocidental: uma abordagem preliminar. In: PATARRA, N. (Org.). Emigração e imigração internacionais no Brasil contemporâneo. São Paulo: FNUAP, 1995. p. 111-121.

BOURDIEU, P. Efeitos do lugar. In: BOURDIEU, P. et al. A miséria do mundo. Petrópolis: Vozes, 2001. p. 159-166

Coisas ditas. São Paulo: Brasiliense, 2004.

Razões práticas: sobre a teoria da ação. Campinas: Papirus, 2011.

BOULY DE LESDAIN, S. Projet migratoire des étudiantes camerounaises et attitude face à l'emploi. Revue Européenne de Migrations Internationales, v. 15, n. 2, p. 189-202, 1999. Disponível em: 〈www.persee.fr/web/revues/home/prescript/article/remi_0765-0752_1999_num_15_2_1685〉. Acesso em: 19 set. 2012.

BOYER, F. Le projet migratoire des migrants touaregs de la zone de Bankilaré: la pauvreté désavouée. Stichproben, n. 8, Special Issue on African Migrations. Historical Perspectives and Contemporary Dynamics, p. 47-67, 2005. Disponível em: «www.univie.ac.at/ecco/stichproben/ Nr8_Boyer.pdf〉. Acesso em: 01 maio 2013.

BRASIL. Ministério das Relações Exteriores. Subsecretaria-Geral das Comunidades Brasileiras no Exterior. Diplomacia Consular: 2007 a 2012. Brasília: Fundação Alexandre de Gusmão, 2012. Disponível em: 〈www.brasileirosnomundo.itamaraty.gov.br〉. Acesso em: 03 nov. 2013.

CARELLI, M. Culturas cruzadas: intercâmbios culturais entre França e Brasil. Campinas: Papirus, 1994.

CASTELLS, M. A nova economia: informacionalismo, globalização, funcionamento em rede. A sociedade em rede. São Paulo: Paz e Terra, 2008. p. 119-208

CASTLES, S.; MILLER, M. La era de la migracion: movimientos internacionales de población en el mundo moderno. México: Cámara de Diputados LIX Legislatura, UAZ, Secretaría de Gobernación, Instituto Nacional de Migración, Fundación Colosio, Miguel Ángel Porrua, 2004. Disponível em: 〈biblioteca.diputados.gob.mx/janium/bv/ce/scpd/LIX/era_mig.pdf〉. Acesso em: 01 abr. 2012. 
CORDEIRO, A. Les portugais, une population ‘invisible?’ In: DEWITTE, P. (Dir.) Immigration et intégration: l'état des savoirs. Paris: La Découverte, 1999. p. 106-111.

DOMENACH, H.; PICOUET, M. El carácter de reversibilidad en el estudio de la migración. Notas de Población, n. 49, p. 49-68, 1990.

DUMONT, G. F. Les nouvelles logiques migratoires au XXIe siècle. Outre-Terre, n. 17, p. 15-25, 2006. Disponivel em: 〈www.cairn.info/revue-outre-terre-2006-4-page-15.htm〉. Acesso em: 18 jul. 2011.

DUMONT, J. C. Les migrations internationales de travailleurs qualifiés: des bénéfices à partager. In: MOUHOUD, E. M. (Dir.). Les nouvelles migrations: un enjeu Nord-Sud de la mondialisation. Paris: Universalis, 2006. p. 79-96.

FERNANDES, D.; NUNAN, C.; CARVALHO, M. O fenómeno da migração internacional de retorno como consequência da Crise Mundial. Revista de Estudos Demográficos, Lisboa, n. 49, p. 69-98, 2011. Disponível em: 〈www.ine.pt〉. Acesso em: 27 ago. 2011.

GLICK-SCHILLER, N. The centrality of ethnography in the study of transnational migration - seeing the wetland instead of the swamp. In: SAHOO, A. K.; MAHARAJ, B. Sociology of diaspora: a reader. New Delhi: Rawat Publications, 2007. p. 118-155.

GUARNIZO, L. E. The economics of transnational living. International Migration Review, v. 37, n. 3, p. 666-699, 2003.

LAURENS, J.-P. Introduction: l'exception et la règle. 1 sur 500: la réussite scolaire en milieu populaire. Toulouse: Presses Universitaires du Mirail, 1992. p. 11-21.

LIVI BACCI, M. A short history of migration. Cambridge, UK; Malden: Polity Press, 2012.

MA MUNG, E. Le point de vue de l'autonomie dans l'étude des migrations internationales: 'penser de l'interieur' lesphénomènes de mobilité. In: DUREAU, F.; HILY, M. A. (Dir.). Les mondes de la mobilité. Rennes: Presses Universitaires de Rennes, 2009. p. 25-38.

MARGOLIS, M. Little Brazil: imigrantes brasileiros em Nova York. Campinas: Papirus, 1994.

MAY, T. Pesquisa social: questões, métodos e processos. Porto Alegre: Artmed, 2004.

MAZZA, D. Intercâmbios acadêmicos internacionais: bolsas Capes, CNPq e Fapesp. Cadernos de Pesquisa, v. 39, n. 137, p. 521-547, 2009.

MOROKVASIC, M. Le genre est au cœur des migrations. In: FALQUET, J. et al. (Dir.). Le sexe de la mondialisation: genre, classe, race et nouvelle division du travail. Paris: Presses de SciencesPo, 2010. p. 105-119.

PALAU, T. Brasiguaios. In: CASTRO, M. G. (Org.). Migrações internacionais: contribuições para políticas. Brasília: CNPD, 2001. p. 345-360.

PATARRA, N.; BAENINGER, R. Migrações internacionais recentes: o caso do Brasil. In: PATARRA, N. (Org.). Emigração e imigração internacionais no Brasil contemporâneo. São Paulo: FNUAP, 1995. p. 78-88.

PEREIRA, M. R. Presença cultural francesa no Brasil. Revista Travessia, São Paulo, n. 65, p. 89-100, 2009.

PIRES, A. P. Amostragem e pesquisa qualitativa: ensaio teórico e metodológico. In: POUPART, J. et al. A pesquisa qualitativa: enfoques epistemológicos e metodológicos. Petrópolis: Vozes, 2010. p. 154-211.

REIS, C. F. Sonhos, incertezas e realizações: as trajetórias de músicos e dançarinos afrobrasileiros no Brasil e na França. Tese (Doutorado) -IFCH/Unicamp, Campinas, 2012. 
ROBERTS, B. R. Socially expected durations and the economic adjustment of immigrants. In: PORTES, A. (Ed.). The economic sociology of immigration. New York: Russell Sage Fundation, 1995. p. $42-86$

ROLLAND, D. L'exil des dictatures: impact conjoncturiel dans la présence latino-américaine en France? In: SANTOS, I. M. F.; ROLLAND, D. L'exil brésilien en France: histoire et imaginaire. Paris: L'Harmattan, 2008. p. 185-205.

ROSENFELD, M. et al. Immigration brésilienne en Europe: dimension transnationale. Hommes \& Migrations, n. 1281, p. 54-63, 2009.

SALES, T. Novos fluxos migratórios da população brasileira. Revista Brasileira de Estudos de População, Campinas, v. 8, n. 1/2, p. 21-32, janeiro/dezembro 1991.

Brasileiros longe de casa. São Paulo: Cortez, 1999.

SASSEN, S. The mobility of labor and capital. Cambridge: Cambridge University Press, 1988.

SCHUTZ, A. The stranger: an essay in social psychology. American Journal of Sociology, v. 49, n. 6, p. 499-507, 1944. Disponível em: 〈www.jstor.org/stable/2771547〉. Acesso em: 21 jan. 2013.

TAVARES, A. L. Brasil-França: ao longo de cinco séculos. Rio de Janeiro: Biblioteca do Exército, 1979.

TILLY, C. Transplanted networks. New York: New Schollof Social Research, 1986.

URRY, J. Societies. Sociology beyond societies: mobilities for thetwenty-firstcentury. Florence: Routledge, 2000. p. 1-20.

VALE, A. F. C. Migração, sexualidade e prostituição: travesti e transgêneros no Bois de Boulogne. In: ENCONTRO ANUAL DA ANPOCS, 33., 2009, Caxambu. Anais... São Paulo: Anpocs, 2009. Disponivel em: 〈www.anpocs.org〉. Acesso em: 10 fev. 2013.

VIDEIRA, P. A mobilidade internacional dos cientistas: construções teóricas e respostas políticas. In: ARAÚJO, E.; FONTES, M.; BENTO, S. (Ed.). Para um debate sobre mobilidade e fuga de cérebros. Braga: Centro de Estudos de Comunicação e Sociedade, Universidade do Minho, 2013. p. 138-162. Disponível em: 〈www.lasics.uminho.pt/ojs/index.php/cecs_ebooks/issue/view/120/showToc〉. Acesso em: 22 jun. 2013.

WAGNER, A. C. Les nouvelles élites de la mondialisation: une immigration dorée en France. Paris: Presses Universitaire de France, 1998.

WEISS, R. S. Respondents: choosingthem and recruitingthem. Learning from strangers: theart and method of qualititave interview studies. New York: The Free Press, 1994. p. 15-37.

WIHTOL DE WENDEN, C. Un essai de typologie des nouvelles mobilités. Hommes \& Migration, n. 1233, p. 5-12, 2001.

XAVIER DE BRITO, A. 'Avec du cœur au ventre': l'expérience des Brésiliens non boursiers à Paris. In: AGULHON, C.; XAVIER DE BRITO, A. (Dir.). Les étudiantes étrangers à Paris. Paris: L'Harmattan, 2009. p. $41-70$

Construction de l'espace de formation brésilien et études à l'étranger. Stratégies et carrière morale des étudiants brésiliens dans l'Université française, 1960-1986. Thèse (Doctorat en Sociologie) - Université René Descartes-Paris, 1991.

ZELIZER, V. L'Économie du care. Revue Française de Socio-Économie, n. 2, p. 13-25, 2008. Disponivel em: 〈www.cairn.info/revue-francaise-de-socio-economie-2008-2-page-13.htm〉. Acesso em: 26 maio 2013. 


\title{
Sobre as autoras
}

Gisele Maria Ribeiro de Almeida é doutora em Sociologia pela Universidade Estadual de Campinas (Unicamp) e professora do Departamento de Ciências Sociais da Universidade Federal Fluminense de Campos dos Goytacazes.

Rosana Baeninger é doutora em Ciências Sociais pela Universidade Estadual de Campinas (Unicamp), professora do Departamento de Demografia do IFCH/Unicamp e pesquisadora do Nepo/Unicamp.

\section{Endereço para correspondência}

\author{
Gisele Maria Ribeiro de Almeida \\ Rua Gilberto Siqueira, 87 ap. 201, Centro \\ 28010-400 - Campos dos Goytacazes-RJ, Brasil \\ Rosana Baeninger \\ Núcleo de Estudos de População “Elza Berquó” - Unicamp \\ Cx. Postal 6166 \\ 13081-970 - Campinas-SP, Brasil
}

\begin{abstract}
Brazilian immigration in France: from historical types to contemporary migratory modalities

The current scenario of intense capital mobility has been accompanied by increasing international population displacements. Social changes experienced in recent decades have introduced greater complexity in the phenomenon of international migration, which takes place under a "new logic", particularly the expansion of the world market, and the dispersion of industry and the production of goods and services. In this context, this article reflects on Brazilian immigration in France after 1980, considering the different migratory modalities that make up this flow. These modalities are redefining the logic of Brazil's insertion in the international migration framework. The multifaceted character of emigration of Brazilians to France reveals that, beyond the historical linkages between the two countries, the new logic of migration on the world geopolitical scenario of this century will result in a more diversified flow of Brazilians toward France. Field research conducted in France in 2012 with eighty two Brazilians immigrants showed a diversity of migrants and migratory modalities profiles. These migratory modalities were engendered from an analysis of migratory projects and reconstructed through semi-structured interviews with immigrants.
\end{abstract}

Keywords: International migration. Emigration-Brazil. Immigration-France. Migration determinants.

\section{Resumen}

La inmigración brasileña en Francia: del tipo histórico a las modalidades migratorias contemporáneas

El escenario actual de la intensa movilidad del capital ha sido acompañado por un creciente desplazamiento internacional de la población. Los cambios sociales experimentados en las últimas décadas hacen más complejo el fenómeno de la migración internacional, que tiene 
lugar en una "nueva lógica", marcada particularmente por la expansión del mercado mundial, y la dispersión de la industria y la producción de los bienes y servicios. En este contexto, este artículo reflexiona sobre la inmigración brasileña en Francia después de 1980, teniendo en cuenta las diferentes modalidades migratorias que conforman este flujo. Tales modalidades redefinen la lógica de la inserción de Brasil en la ruta de la migración internacional. El carácter multifacético de la emigración de los brasileños a Francia revela que, más allá de los vínculos históricos entre los países, la nueva lógica de la migración en la escena geopolítica mundial de ese siglo se reflejará en la diversificación de flujos de brasileños y brasileñas hacia Francia. La investigación de campo que fue realizada en Francia en 2012, con ochenta y dos inmigrantes brasileños y brasileñas mostró que existe una diversidad de los migrantes y de los perfiles de modalidades migratorias. Estas modalidades migratorias fueron engendradas a partir de los proyectos de inmigración y reconstruidos con las entrevistas semiestructuradas realizadas a los inmigrantes.

Palabras clave: Migración internacional. Emigración-Brasil. Inmigración-France. Determinantes de la migración.

Recebido para publicação em 25/05/2015

Recomendado para publicação em 27/03/2016

Aceito para publicação em 09/04/2016 


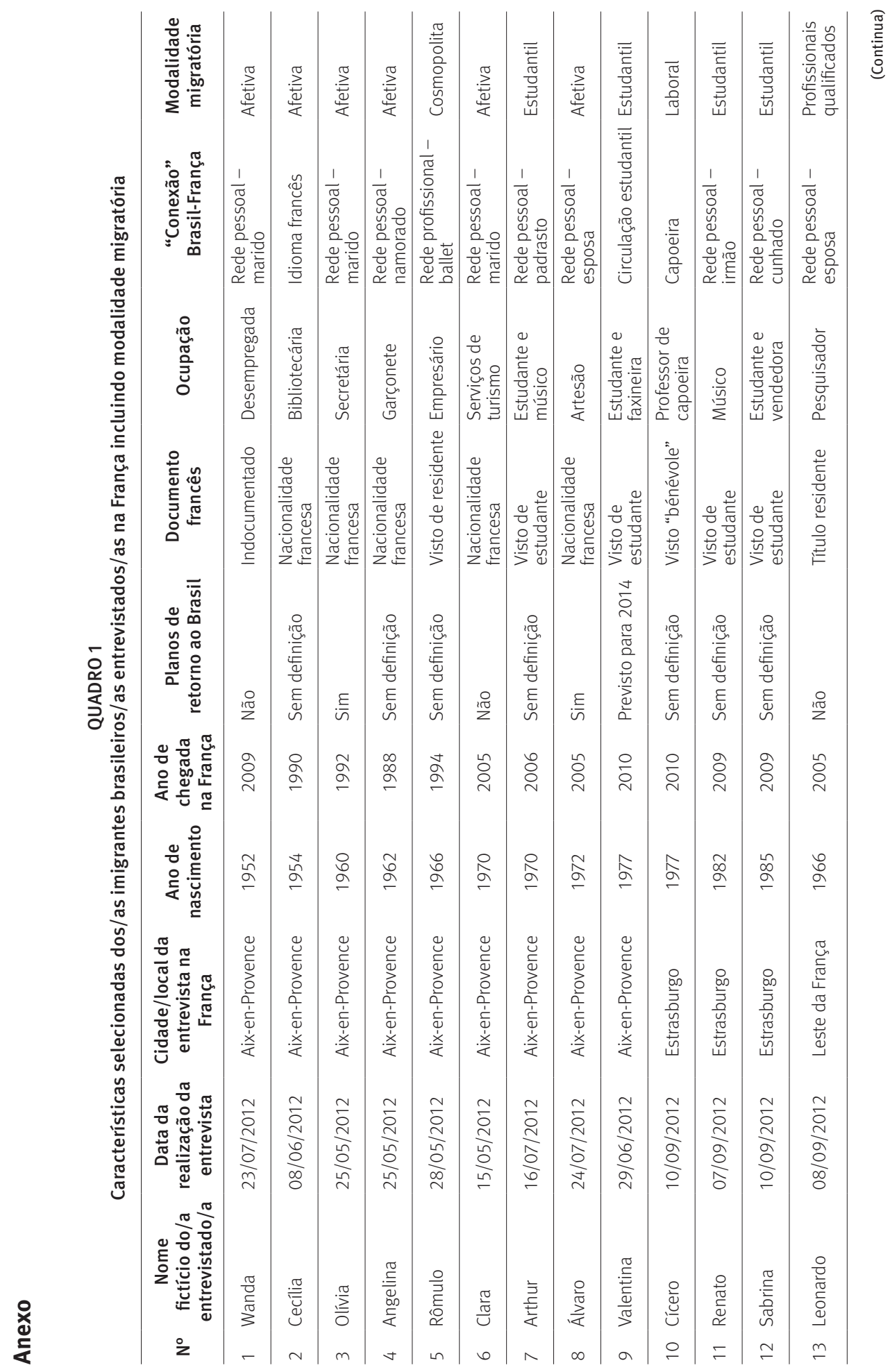




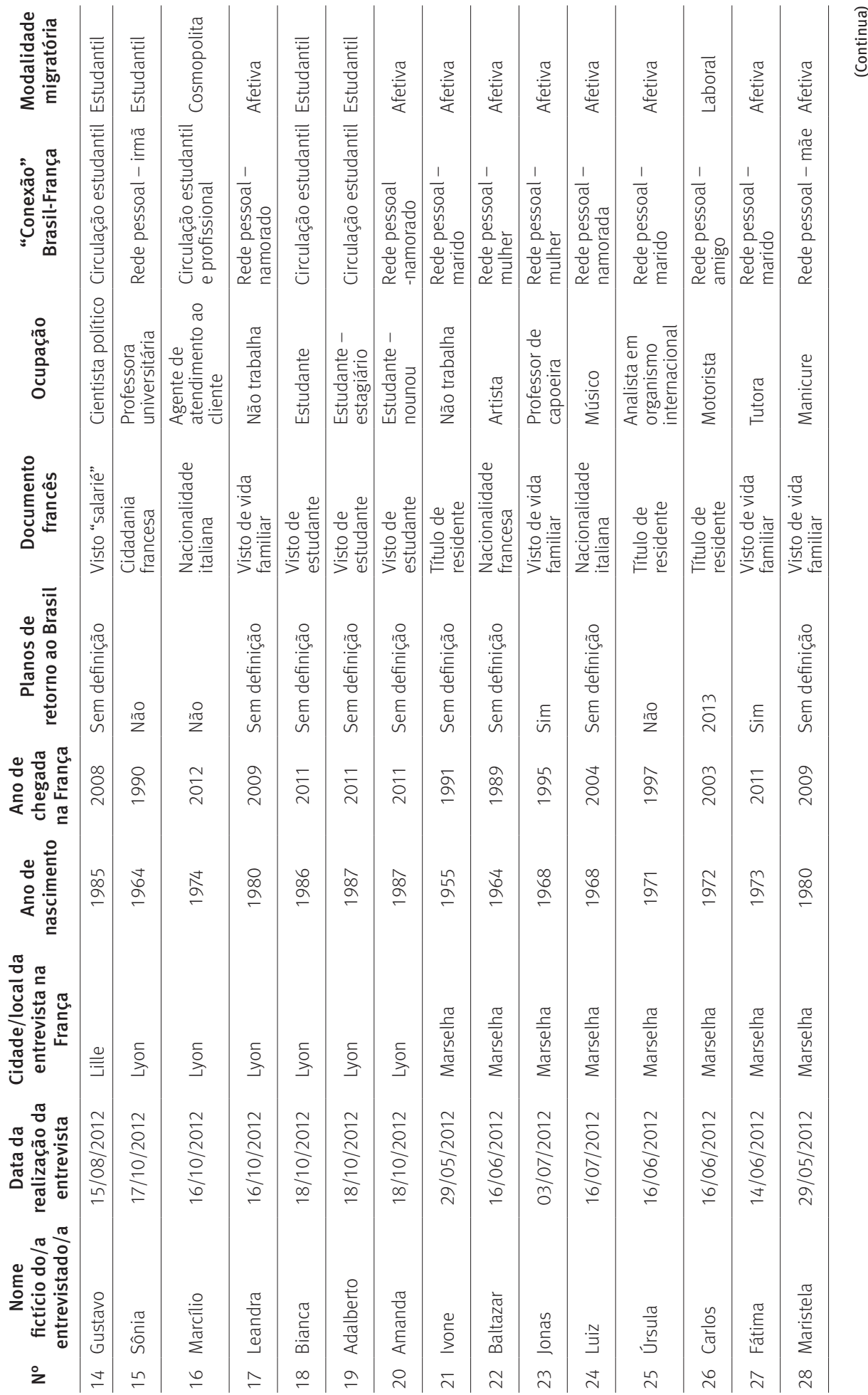




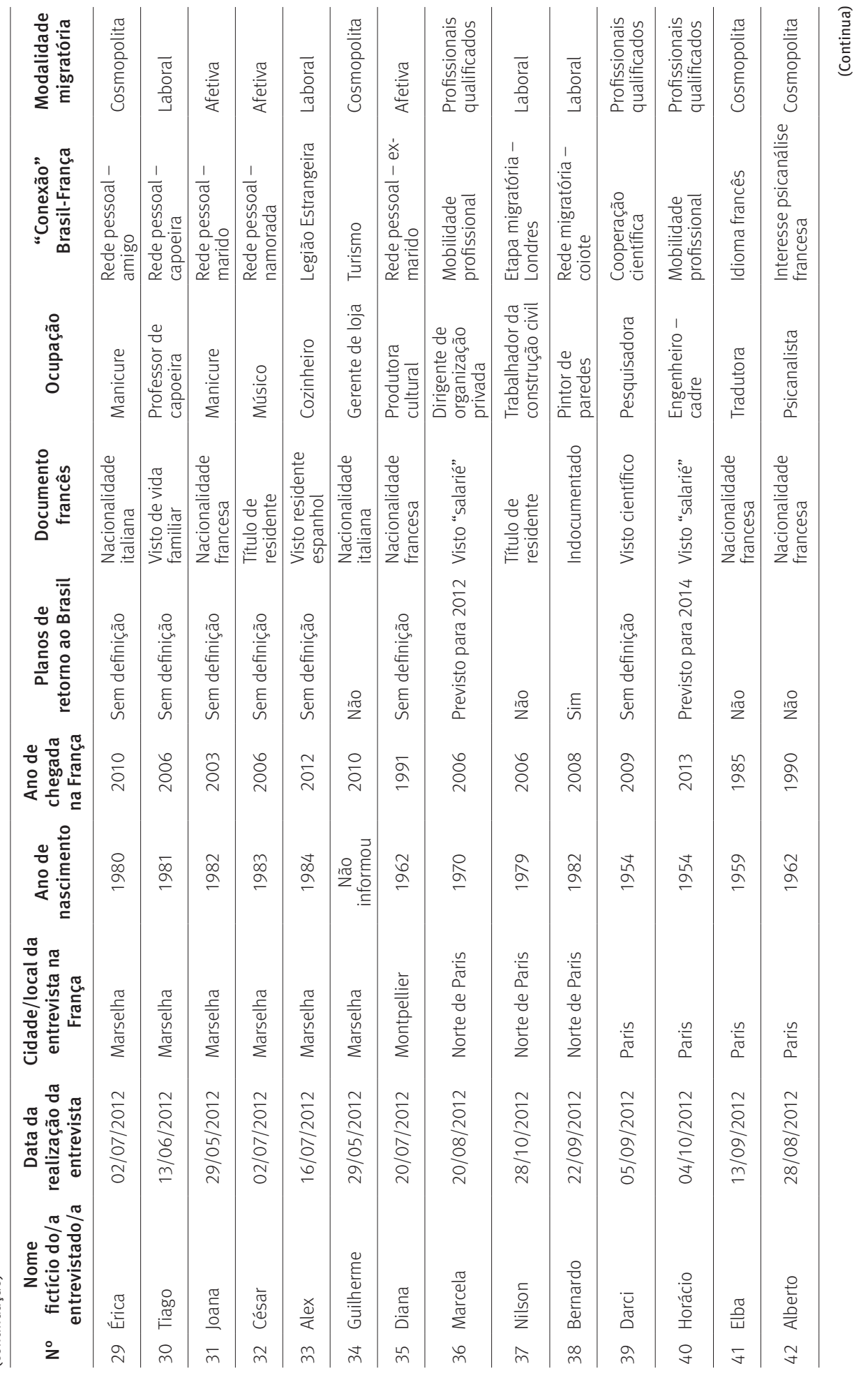




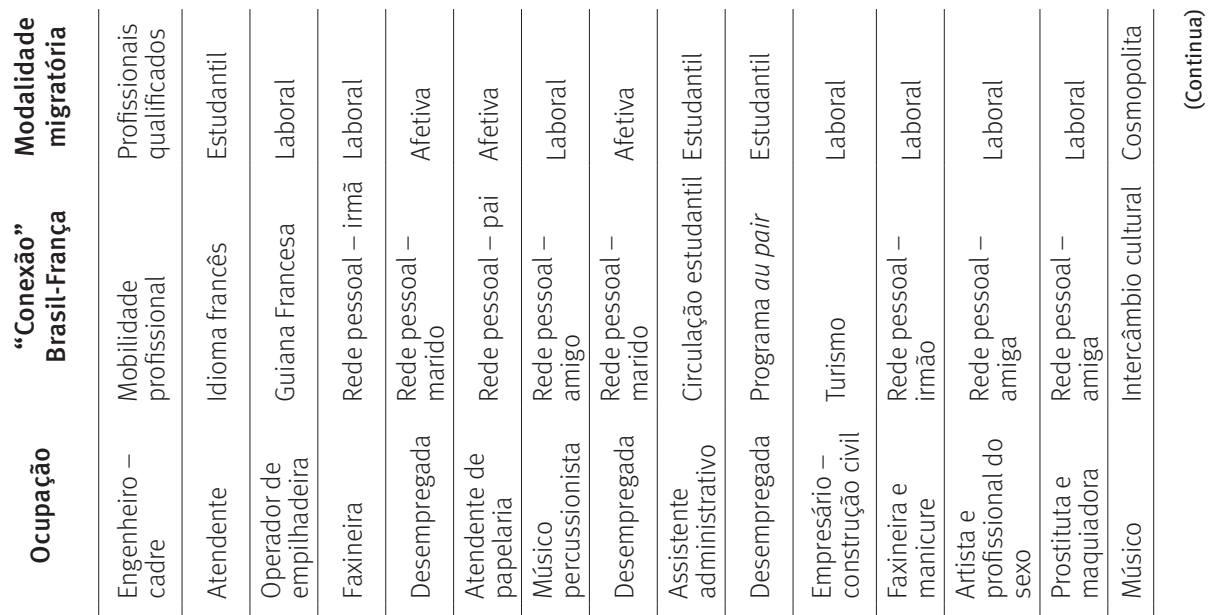

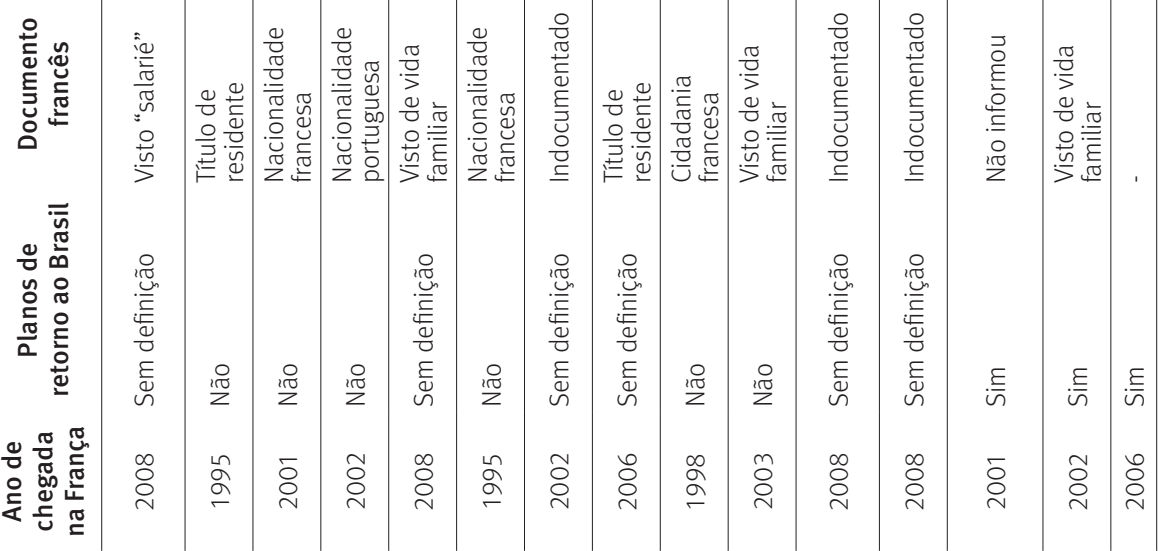

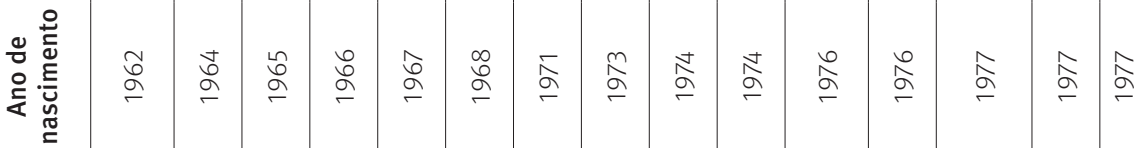
$\frac{\pi}{\frac{\pi}{0}} \stackrel{\pi}{=}$

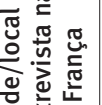

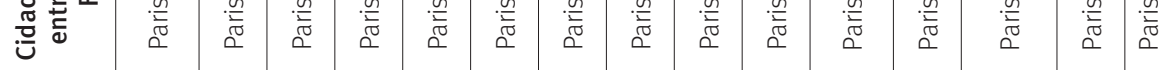

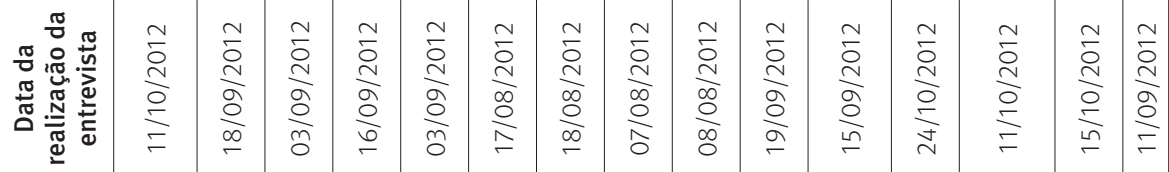

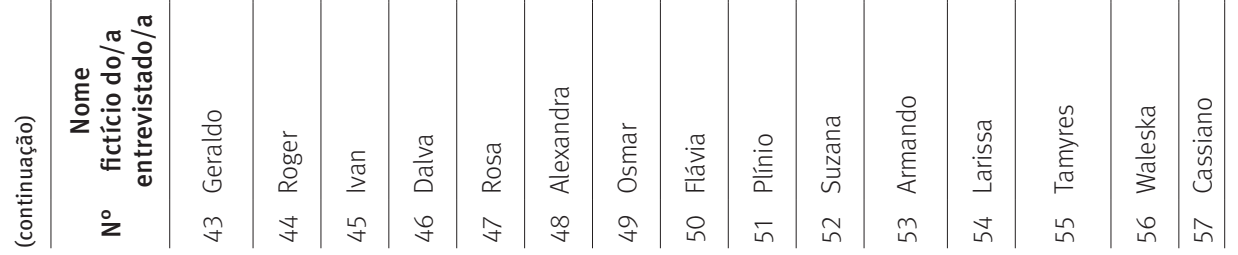




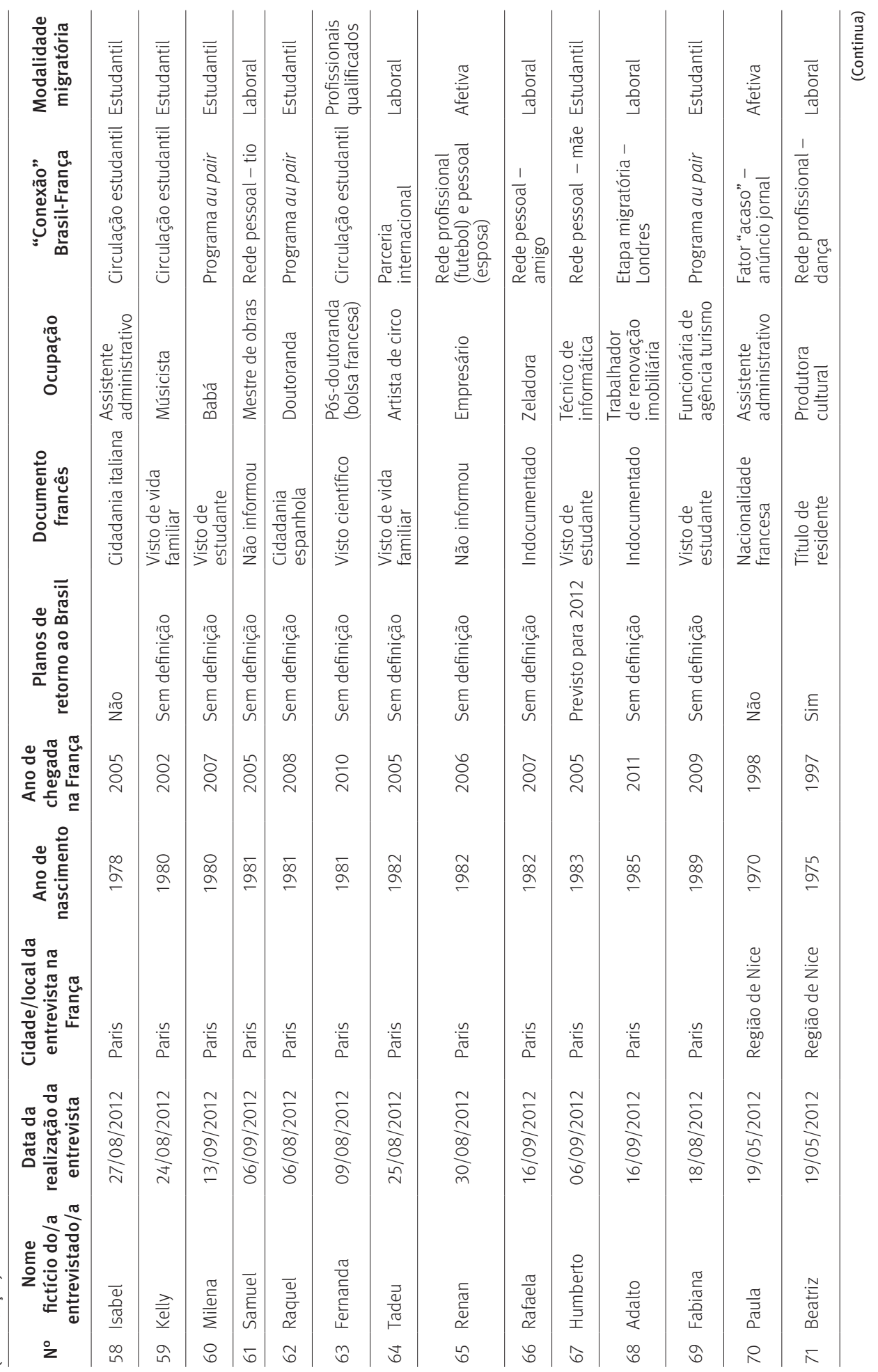




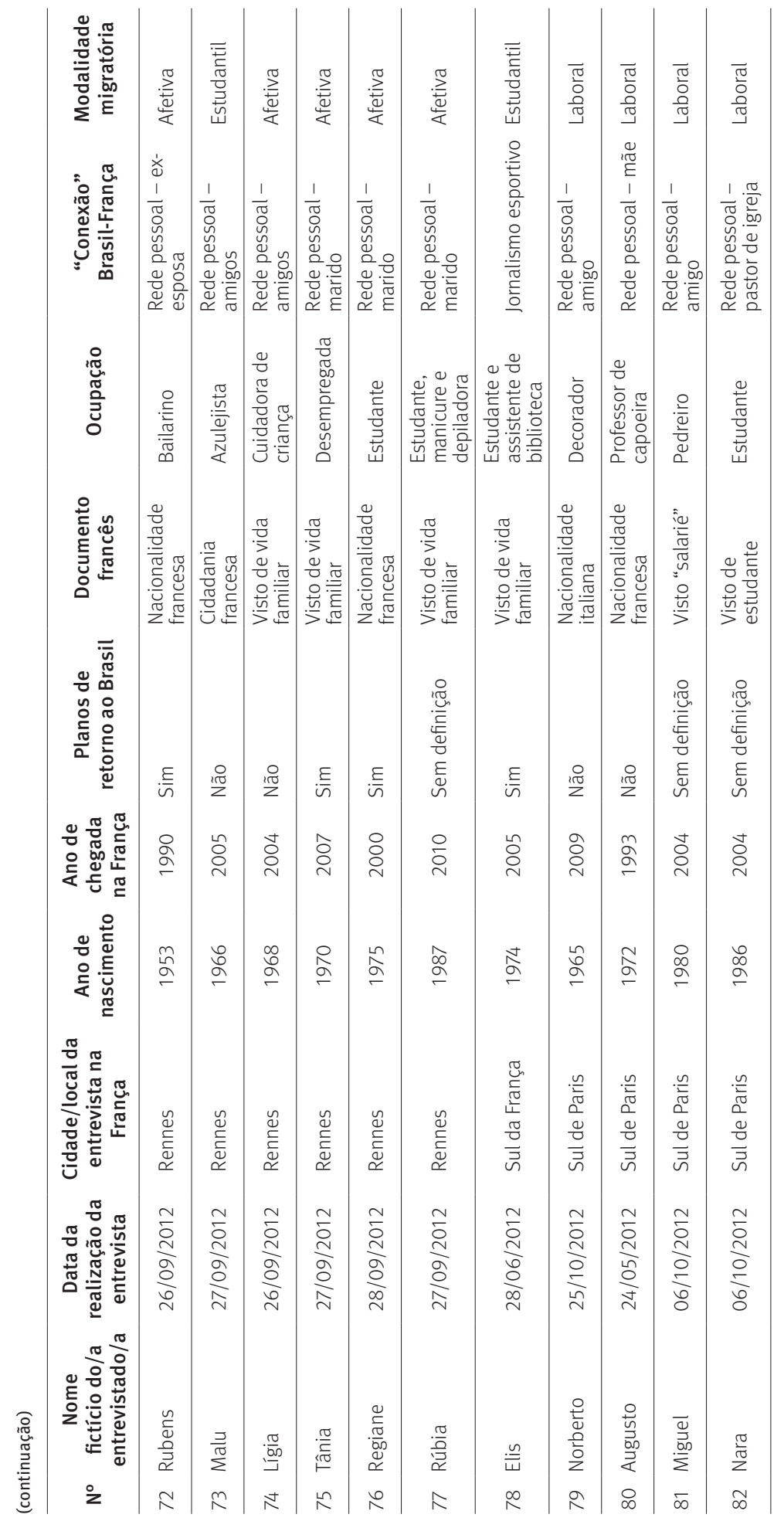


